\title{
Legislating Incentives for Attorney Representation in Civil Rights Litigation
}

Douglas M. Spencer

University of Connecticut School of Law

Sean Farhang

University of California, Berkeley

Follow this and additional works at: https://opencommons.uconn.edu/law_papers

Part of the Civil Rights and Discrimination Commons, and the Labor and Employment Law Commons

\section{Recommended Citation}

Spencer, Douglas M. and Farhang, Sean, "Legislating Incentives for Attorney Representation in Civil Rights Litigation" (2014). Faculty Articles and Papers. 465.

https://opencommons.uconn.edu/law_papers/465 


\title{
Legislating Incentives for Attorney Representation in Civil Rights Litigation
}

\author{
SEAN FARHANG, University of California, Berkeley
}

DOUGLAS M. SPENCER, University of Connecticut

\begin{abstract}
Congress routinely relies on private lawsuits to enforce its mandates. In this article, we investigate whether, when it does so, the details of the legislation can importantly influence the extent to which the private bar is mobilized to carry out the prosecutorial function. Using an original and novel data set based on review of archived litigation documents for cases filed in the Northern and Eastern Districts of California over the two decades spanning 1981-2000, we examine the effects of the Civil Rights Act of 1991, which increased economic damages available to Title VII job discrimination plaintiffs, on their ability to secure counsel. We find that over the course of the decade after passage, the law substantially increased the probability that Title VII plaintiffs would be represented by counsel and that in doing so it reversed a decade-long trend in the opposite direction.
\end{abstract}

\section{INTRODUCTION}

Congress's reliance on economic incentives to mobilize private counsel to enforce statutory mandates cuts across virtually every area of regulatory policy and is a defining facet of the modern American state (Melnick 1994; Kagan 2001; Burke 2002; Farhang 2010). In this article, we investigate whether, when Congress relies on private lawsuits to implement a law, the details of the legislation can importantly influence the extent to which the private bar is mobilized to carry out the prosecutorial function. In 1991, Congress amended Title VII of the Civil Rights Act of 1964 to increase the economic

We are grateful to Kevin Clermont, Bert Kritzer, Gwendolyn Leachman, Justin McCrary, J. J. Prescott, Kevin Quinn, Shauhin Talesh, and Abby Wood for helpful comments and suggestions. Earlier drafts of this article were presented at the 2012 annual meeting of the American Law and Economics Association, the 2011 annual meeting of the Law and Society Association, and the Berkeley Empirical Legal Studies colloquium at the Berkeley Law School in 2011. We thank the American Bar Association's Litigation Research Fund for its generous support of this project. Contact the corresponding author, Douglas Spencer, at doug.spencer@law.uconn.edu. 
value of job discrimination claims. One of Congress's express purposes was to address a perceived undersupply of attorneys to effectuate Title VII enforcement. Exploiting the sharp disjuncture in the economic value of Title VII claims introduced by the Civil Rights Act of 1991, we empirically assess whether and, if so, to what degree the law affected Title VII plaintiffs' ability to secure counsel. We conclude that the law dramatically increased the probability that plaintiffs were represented.

\section{PRIVATE ENFORCEMENT REGIMES}

When Congress seeks to regulate economic or social life through statutory commands, it must choose implementing the law through administrative authority, litigation in courts, or some combination of the two in a hybrid approach (e.g., Fiorina 1982; Eskridge, Frickey, and Garretr 2001, 1099; Kagan 2001; Bardach and Kagan 2002; Burke 2002). When Congress includes a private right of action in a statute, it faces a series of choices such as who has standing to sue, what the rules are for governing the allocation of responsibility for attorney's fees and other costs of litigation, what monetary damages and other remedies will be available to winning plaintiffs, and whether the parties will be entitled to demand trial by jury. Together such choices can have substantial consequences for how much or little private enforcement litigation will actually be mobilized (Melnick 1994, 2005; Kagan 2001; Burke 2002; Frymer 2007, chap. 4). We refer to this constellation of rules as a statute's "private enforcement regime."

\section{A. Economic Incentives and Private Enforcement}

Our conceptualization of how private enforcement regimes mobilize private litigation pivots on economic incentives for plaintiffs and their lawyers to file suit. To be sure, the choice of whether or not to sue may be influenced by forms of utility or disutility distinct from, and not reducible to, money. We focus on economic incentives because, from the standpoint of institutional design, they can be readily deployed by legislative drafters seeking to mobilize private enforcement, which is the focus of our analysis.

On the stylized law and economics account of the choice to litigate, a prospective plaintiff will sue when a case's expected monetary value $(E V)$ if tried is positive, where $E V$ is a function of the plaintiff's estimate of the expected monetary benefit of the case if she prevails $(E B)$, the probability that she will prevail if the case goes to trial $(p)$, and the expected costs of litigating the claim $(E C)$. Thus, $E V=E B(p)-E C$, and the rational plaintiff will file suit if $E V$ is positive (Posner 1973; Priest and Klein 1984; Polinsky and Shavell 1998; Cooter and Ulen 2004).

Expected benefits, expected costs, and probability of success can all be influenced by the details of a statutory private enforcement regime (Farhang 2010, chap. 2). Expected benefits $(E B)$ are determined to an important extent by rules governing how much monetary damages a plaintiff will be able to recover (Galanter and Luban 1993; Polinsky and Shavell 1998). Expected costs are the sum of the filing fee, attorney's fees, and other costs of litigation (Shavell 1982; Zemans 1984; Kritzer 2001). Probability of success is, of 
course, strongly influenced by case facts but also by rules governing burdens and standards of proof, discovery, evidence, and liability (Cooter and Rubinfeld 1994; Kornhauser and Revesz 1994; Cooter and Ulen 2004, 431-32).

In order to understand actual litigation activity, one must pay particular attention to the incentives faced by attorneys (Galanter 1974; Johnson 1980; Zemans 1984; Galanter and Luban 1993; Kritzer 2004). Plaintiffs' lawyers in the United States are regularly dependent on the profitable resolution of a case for some or all of their compensation due to the inability of plaintiffs to cover the often massive expenses of a lawsuit. This is commonplace in statutory regulation where private enforcement regimes are utilized. Lawyers representing plaintiffs alleging violations of statures in the areas of civil rights, labor, securities, antitrust, consumer, and environmental regulation, for example, are often compensated, in full or in part, on the basis of statutory fee awards, a share of damages provided by statute, or some combination of the two (Derfner 1977; Zemans 1984; Greve 1989; Davies 1997; Mongoven 2005; Goldfarb et al. 2006; Drahozal 2009, 750 ; Farhang 2010). When for-profit lawyers' compensation is based on the proceeds of successful litigation, their willingness to represent plaintiffs will typically center on both their assessment of the likelihood of establishing liability and their estimate of the extent of monetary recovery available (Johnson 1980; Galanter and Luban 1993; Davies 1997; Kritzer 2004).

We stress that one cannot presume that potential plaintiffs and counsel will evaluate expected value in the same way. In addition to noneconomic considerations, potential plaintiffs may estimate their probability of success as higher, or the magnitude of their compensable injuries as larger, than a potential attorney would. This may provide a partial explanation for the fact that some plaintiffs who seek and are unable to obtain counsel elect to proceed with litigation pro se.

\section{B. The Importance of Attorney Representation to Private Enforcement}

The efficacy of private enforcement regimes for policy implementation turns on Congress's capacity to mobilize attorneys, not just plaintiffs. Litigation in courts is a complex process riddled with technicality, and unrepresented plaintiffs have great difficulty navigating it effectively without counsel. Empirical studies have found that litigants represented by counsel in court proceedings are far more effective than pro se plaintiffs in enforcing statutory rights. Across multiple policy areas, researchers have found that represented litigants are less likely to have their cases dismissed, more likely to have judgments entered in their favor, more likely to secure more of the relief sought, and more likely to achieve settlement (Fusco, Collins, and Birnbaum 1979; Schwab and Eisenberg 1988; Seron et al. 2001; McDermott and Obar 2004; Pardo 2009; Nielsen, Nelson, and Lancaster 2010; Pattanayak, Greiner, and Hennessy 2013).

The question naturally arises whether these differential effects are driven by the attorney screening process: perhaps litigants with better cases are more likely to secure representation, and thus represented plaintiffs do better because of the quality of their 
cases, not because they are represented. As noted above, however, the attorney screening process involves an assessment of not just the merits of a case but also, given the merits, available economic recoveries. Further, we note that the studies by Seron et al. (2001) and Pattanayak et al. (2013) deployed powerful research designs to guard against this selection bias issue. Lawyers were randomly assigned to a group of unrepresented litigants, and those with lawyers did far better than those without. ${ }^{1}$

The foregoing discussion of economic incentives and private enforcement regimes connects directly to an important line of research concerning the significance of certain forms of legal infrastructures to the elaboration and protection of rights through courts. Marc Galanter (1974) famously argued that "repeat players" (who use the courts frequently and are typically "haves") possess significant advantages over "one-shotters" (who use the courts infrequently and are typically "have-nots"). The advantages importantly include access to greater legal resources, skill, and expertise in the litigation process, and Galanter speculated that one way to counterbalance the inequality between repeat players and one-shotters could be through legal rules and policies that have the effect of increasing the supply of quality legal services for have-nots. The logic linking economic incentives to private enforcement regimes highlights that the existence of an important "support structure" (Epp 1998) to enforce statutes - a bar of ready, willing, and able lawyers - may be significantly a function of legislative design.

\section{THE CONSEQUENCES OF LEGISLATIVE INCREASES IN EXPECTED VALUE}

\section{A. Empirical Research on Changes in Expected Value}

Two studies have evaluated whether Congress increased the assertion of claims by increasing their economic value, though they did so without regard to whether claimants

1. We stress that we are here focused on the issue of representation in judicial proceedings. A recent paper examining administrative hearings on unemployment claims finds that claimants who were offered representation by a student law clinic were not more likely to prevail in the proceedings than people who sought help from the clinic but were denied (Greiner and Pattanayak 2012). In general, administrative tribunals evaluating entitlement to benefits, as contrasted with judicial proceedings, are designed to process large numbers of claims more quickly and cheaply and to reduce or obviate the need for counsel. Administrative hearing officers typically are not bound by rigid rules of evidence or civil procedure, rendering their proceedings less formal and complex, and they have greater flexibility in how they conduct hearings, often seeking to facilitate consideration of relevant issues for unrepresented parties (Mashaw 1974; Walters $v$. National Ass $n$ of Radiation Survivors, 473 U.S. 305, 319-33 [1985]). Courts generally eschew this "inquisitorial" role of actively shaping the development and presentation of a case, while sometimes insisting that it is the duty of an administrative adjudicator to do so (Long 2009, 139, n. 126). The utility of a lawyer in a mass administrative proceedings is a question quite different from the utility of a lawyer in procedurally complex federal civil rights lawsuits - which are the focus of this article-where discriminatory intent typically must be proved, and where substantial discovery, including taking and defending depositions, is often extremely important. 
were represented by counsel. Schwab and Eisenberg (1988) evaluated the effects of the Civil Rights Attorneys Fees Awards Act of 1976, which created a plaintiffs' fee-shifting provision to govern numerous already-existing civil rights statutes, including section 1983 actions for violations of federal constitutional rights by state officers. They found, at best, "scant evidence" that the law affected the volume of filings (1988, 760-61). Farhang (2009) evaluated the effects of the Civil Rights Act of 1991 — which markedly increased monetary damages available under Title VII of the CRA of 1964-on the volume of Title VII charges filed with the Equal Employment Opportunity Commission (EEOC). He finds that the law produced a $58 \%$ increase in Title VII charges before the EEOC (27). While filing an EEOC charge is a formal legal precondition to suit, claimants in a large majority of EEOC charges are unrepresented by counsel and do not file litigation following that administrative process (LeRoy and Feuille 2003, 290; Taylor 2009, 147; Hickox 2010, 160). Neither of the above studies sheds light on the issue of representation.

In this article, we investigate the effects of the CRA of 1991 on the probability that Title VII plaintiffs were represented by counsel, and we provide the first empirical study to test the effectiveness of a self-conscious congressional effort to bolster attorney representation, in the face of extensive pro se litigation, via increasing the economic value of claims. We do so in an area in which Congress perceived a problem that victims of unlawful conduct were unable to secure counsel and therefore were unable to meaningfully enforce the public policies embodied in a statute. Given the importance of representation to meaningful and effective litigation, evaluating whether Congress succeeded in its stated goal of increasing representation, and if so, to what extent, has important implications for the design of regulatory implementation.

\section{B. Theorizing Linkages between Changes in Expected Value and Representation}

Predicting how an increase in expected value will influence the probability of representation is not straightforward. Since an increase in expected benefits can enlarge the population of claims that potential counsel and/or plaintiffs regard as having positive expected value, it can affect the overall mix of characteristics in the pool of potential claims in ways associated with plaintiffs' ability to secure counsel. This is complicated further by the fact that changes in expected value may mobilize pro se litigation as well as represented litigation because potential plaintiffs may assess expected value as positive where counsel judges it to be negative. Thus, predicting how an increase in expected value will influence the probability of representation hinges on speculative assumptions. A few simple examples serve to illustrate the nature of these assumptions and how variation in them can lead to different outcomes for the probability of representation.

Recall the equation $E V=E B(p)-E C$, where the expected value of a claim is a function of expected benefits, probability of success, and expected costs. Many factors 
influence probability of success, including case facts. Consider case facts as they affect probability of success to be $f p$, where higher values of $f p$ are associated with stronger case facts. Clearly, an increase in recoverable damages $(E B)$ via a legislative intervention, other things equal, may induce the filing of claims with lower values of $f p$.

In panel $A$ of figure 1, the legislative intervention occurs in a status quo with 100 suits, where $60 \%$ of plaintiffs are represented and $40 \%$ are pro se. There are two types of claims: $f p_{1}$ claims were litigared preintervention and continue to be litigated postintervention; $f p_{2}$ claims were not litigated preintervention but are litigated postintervention, and would not be litigated but for the intervention; and $f p_{1}$ claims have stronger case facts than $f p_{2}$ claims $\left(f p_{1}>f p_{2}\right)$. Thus, $f p_{2}$ claims are, as compared to $f p_{1}$ claims, factually weaker cases that were drawn into litigation by the increase in recoverable damages. Postintervention, one can conceptualize two distinct representation dynamics. First, with respect to the 100 claims of the type already being litigated preintervention $\left(f p_{1}\right.$ claims), it seems clear, as a matter of theory, that we would expect an increase in representation. From the standpoint of counsel, other things equal, some fraction of the $f p_{1}$ claims will move from negative to positive expected value because of the increase in available damages. In the postintervention portion of panel $A$, there is an increase in representation to $80 \%$ for $f p_{1}$ claims.

At the same time, however, there are $50 f p_{2}$ claims drawn into litigation that are factually weaker and of a type that had not been litigated preintervention. Among these, 30 are represented, while the remaining 20 proceed pro se. When $f p_{1}$ and $f p_{2}$ claims are aggregated, $73 \%$ of plaintiffs (110 of 150) secure representation in the postintervention period. Relative to the status quo of $60 \%$ representation, the effect of the increase in recoverable damages was to significantly increase the probability of representation in the postintervention pool of litigants as compared to the preintervention pool.

In the second scenario, depicted in panel $B$ of figure 1, the intervention occurs in the same status quo. As distinguished from the first scenario, (1) twice the number of factually weaker $f p_{2}$ claims are newly drawn into litigation ( 100 instead of 50), and (2) a smaller fraction of them secure representation ( $40 \%$ instead of $60 \%$ ). Now, when $f p_{1}$ and $f p_{2}$ claims are aggregated, in the postintervention period, $60 \%$ of plaintiffs (120 of 200) secure representation. Consistent with reasonable theoretical expectations, $f p_{1}$ claims, which were already being litigated preintervention, became more likely to secure counsel as a result of the increase in available damages. However, these representation gains were exactly offset by lower levels of representation in the newly mobilized and factually weaker $f p_{2}$ claims, and thus the overall postintervention level of representation was unchanged as compared to the preintervention level.

Finally, the third scenario, depicted in panel $C$ of figure 1, represents a decrease in representation. As distinguished from the second scenario, we make only one change: in the postintervention period, a smaller percentage of claims already being litigated preintervention ( $f p_{1}$ claims) secure representation (70\%). This remains consistent 


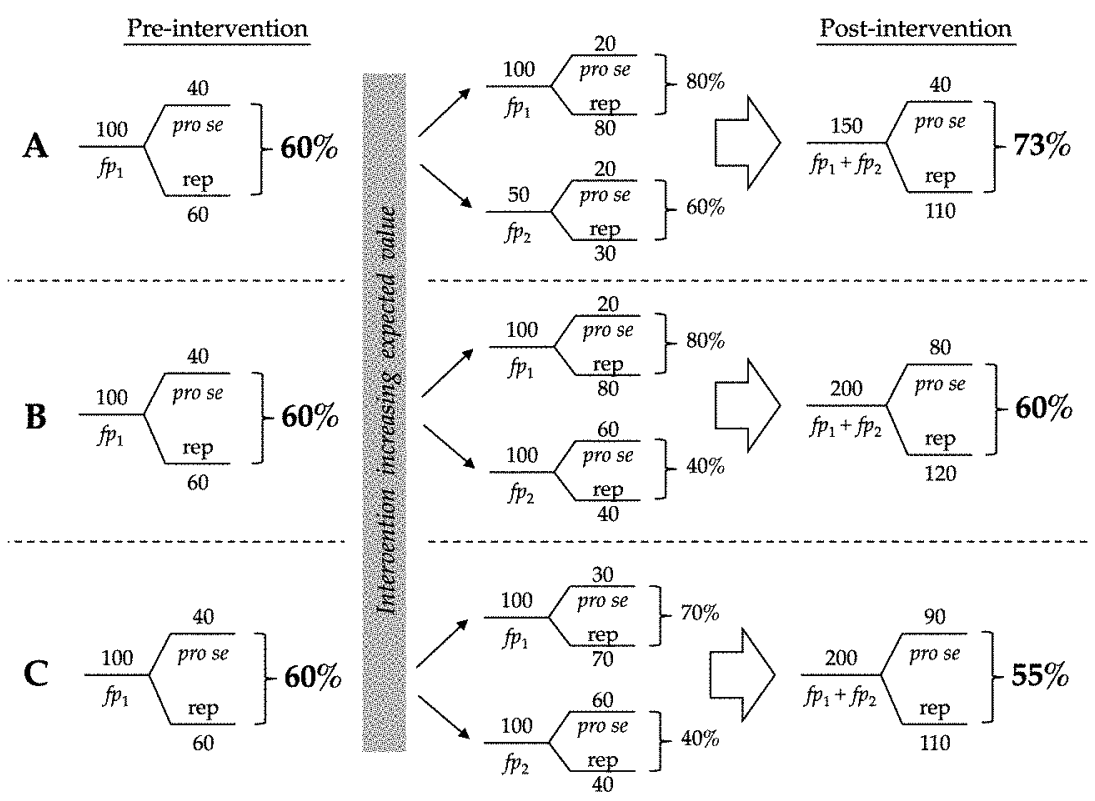

Figure 1. Decision tree representing the effect of increasing the expected value of a case on representation. The percentage of plaintiffs with counsel is reported for each decision node. The figure illustrates how changes in expected value may mobilize pro se litigation as well as represented litigation because potential plaintiffs may assess expected value as positive when counsel judges it to be negative.

with reasonable theoretical expectations: there is an increase in representation among claims already being litigated preintervention, but by a lesser degree than in the first two scenarios. In the third scenario, when $f p_{1}$ and $f p_{2}$ claims are aggregated, $55 \%$ of plaintiffs ( 110 of 200 ) secure representation in the postintervention period. This scenario suggests the clear logical possibility that an intervention aimed at increasing representation via increasing damages could have the effect of reducing representation in the overall population of claims litigated postintervention.

These examples illustrate why it is difficult to generate strong predictions about the effect of an increase in expected value on the probability of representation. It could increase levels of representation, have a null effect, or decrease levels of representation. A prediction of which state of affairs will result from the intervention would hinge on expectations about the magnitude of the effect on representation for claim types already being litigated preintervention ( $f p_{1}$ claims), the number of claims that will be newly drawn into litigation as a result of the intervention ( $f p_{2}$ claims), the fraction of those $f p_{2}$ claimants that will secure counsel, and the propensity of unrepresented $f p_{2}$ claimants to proceed pro se.

The possibility of changes in the pool of Title VII claims after the CRA of 1991 points to both a limitation and a strength of our study. The limitation is that we are not able to 
evaluate the effects of pre- and post-CRA of 1991 incentives on the identical population of claims, which would allow the cleanest possible (experiment-like) assessment of the effects of changes in expected value on representation. However, it will always be the case, in reality, that when legislators seek to increase representation via increasing expected value, the increase in expected value will have the potential to affect aggregate filings and the nature of cases filed. Studying patterns of representation in this complex reality, as we do, thus has the potential to yield insights that are useful to those who design public policy in the real world.

If we discover that the act had the effect of reducing the overall probability of representation, this would provide cautionary evidence about the feasibility of solving the problem of underrepresentation by increasing expected value. Pro se litigants impose cost and delay on an adversarial system that is designed on the assumption of attorney representation, and numerous judicial administrative bodies and scholarly commentators have accordingly identified growing pro se litigation as a serious problem of judicial administration (Rosenbloom 2002; Landsman 2009; Thompson 2010). Further, the great difficulty that pro se litigants have in navigating judicial proceedings fuels their alienation from the judiciary, compromises its legitimacy, and erodes its authority among the growing ranks of pro se litigants (Rosenbloom 2002; Landsman 2009; Thompson 2010). From a policy design point of view, materially increasing pro se litigation has policy costs.

On the other hand, if we find that the CRA of 1991 brought about a substantively significant increase in representation, this would suggest that the positive operation of the increase in expected value predominated over any incentivization of more pro se claims within the overall pool of suits litigated. Of course, one could not generalize carelessly from this finding that it will hold in all contexts. Fuller understanding of this subject can be built only on a body of studies focusing on a range of contexts. We endeavor to offer the first.

\section{THE CIVIL RIGHTS ACT OF 1991 AND TITLE VII CLAIMS}

A. The Origins of the Act

The bill that led to the Civil Rights Act of 1991 was initially motivated to override a series of five Supreme Court decisions handed down in May and June of 1989 interpreting Title VII of the Civil Rights Act of 1964 . These cases, and several others that were decided while the override process was under way, all sought to cut back Title VII's private enforcement regime. They spanned burdens of proof, standards of evidence, standing, statutes of limitations, attorney's fees, and expert witness costs (Govan 1993; Farhang 2010, chap. 6). In each of the cases the Supreme Court adjusted Title VII's private enforcement regime to the detriment of women and minority plaintiffs, reducing opportunities and incentives for private enforcement actions. 


\section{B. The Content of the Act}

In the CRA of 1991, a Democrat-controlled Congress overrode a large majority of the seven cases. The express goal of the statute was to substantially restore Title VII law to its condition prior to the decisions being overridden (Govan 1993; Farhang 2010, chap. 6). However, the CRA of 1991's most important changes went well beyond overriding the Supreme Court. The law added new economic incentives to Tirle VII's private enforcement regime that were calculated to increase plaintiffs' ability to secure representation by counsel and thereby to bolster private enforcement. Prior to the amendments, while winning plaintiffs could recover attorney's fees, money damages were limited to back pay. The CRA of 1991 provided that plaintiffs could additionally recover compensatory damages, including for emotional pain and suffering, as well as punitive damages (42 U.S.C. $\$ 1981 \mathrm{a}[\mathbf{a}]){ }^{2}$ This change in available damages transformed claims that had previously carried little or no money value into claims with potentially substantial monetary worth. It thereby increased the expected value of many Title VII lawsuits from the standpoint of both plaintiffs and their lawyers.

A related factor that likely increased the perceived expected value of Title VII claims was a provision that created a right to trial by jury in cases seeking compensatory or punirive damages. Prior to 1991, no right to trial by jury existed for Title VII claims. The addition of the jury trial right was tied to the new damages provisions. The Seventh Amendment of the US Constitution guarantees the right to jury trial in actions brought in federal court to enforce "legal" rights and remedies, including suits seeking compensatory or punitive damages (Murphy 1995, 351-56). At least partly in recognition of this constitutional requirement, the CRA of 1991 created an express right to jury trial in suits seeking such damages (42 U.S.C. $\$ 1981 \mathrm{a}[\mathrm{c}]$; Govan 1993). Thus, in claims seeking compensatory or punitive damages under the CRA of 1991, the liability determination of whether a plaintiff had been discriminated against and, if so, the damages determination of how much money to award her would be in the hands of a cross section of the population rather than a federal judge (at the time most likely to be white, male, and Republican). Both civil rights activists and those advocating the interests of the business community perceived that juries would, on balance, be more favorable to plaintiffs than would federal judges (Govan 1993). ${ }^{3}$ That is, they believed that, as compared to bench trials, the right to trial by jury under the CRA of 1991 would increase Title VII plaintiffs' chances of prevailing, as well as the magnitude of damages likely to be awarded. In the probable event that plaintiffs' lawyers share this perception, the right to trial by jury, along with the new damages provisions, would thus increase their estimate of the expected value of Title VII claims.

2. The noneconomic damages had graduated caps depending on the size of the employer.

3. We note that empirical research on the actual effect of juries does not necessarily support this perception (Viscusi 1991; MacCoun 1999; Sunstein et al. 2002; Robbennolt 2005). 
For purposes of later analysis, it is important to emphasize that the CRA of 1991 changed Title VII law in two distinct ways. First, it overruled a set of Supreme Court decisions, substantially restoring the law to its condition in April 1989. Second, the law created wholly new damages and jury trial provisions. Thus, as compared to the Title VII status quo as it existed in April 1989, the new regime of Title VII law created by the CRA of 1991 was distinguished only by the new damages and jury trial provisions.

\section{The Motivations for the New Damages and Associated Jury Trial Provisions}

The legislative history of the CRA of 1991 reveals that one of Congress's primary motivations in enacting the new damages provisions, in the face of extensive pro se Tithe VII litigation, was to mobilize counsel (Farhang 2010, chap. 6). Legislative supporters of the new damages provisions maintained that many plaintiffs with meritorious claims were unable to secure counsel (190). In support of this belief, Congress relied on evidence, including a report from the Federal Courts Study Committee, suggesting that the availability of fee awards under existing law was often insufficient to attract Title VII counsel because of uncertainty and long delay before fees could be recovered, narrow judicial construction of fee-shifting rules, and difficulty in recovering fees at marker rates even when fee petitions were successful (190-91). Both the House and Senate reports on the issue explicitly maintained that there was an insufficient bar of attorneys willing to represent job discrimination plaintiffs with meritorious claims and that this problem resulted from inadequate economic incentives to do so (191-92). Compensatory and punitive damages, legislative advocates believed, would allow contingency arrangements to counteract the discounting of fees resulting from delay and uncertainty of fee recovery (192). To a significant degree, the new damages provisions were expressly justified as an instrument to mobilize more lawyers in the service of Title VII enforcement. Did it work?

\section{v. OUR DATA}

Prior to the mid-1990s, the litigation data maintained by the Administrative Office of the United States Courts (AO) rarely recorded whether plaintiffs were represented by counsel and rarely recorded which statute(s) job discrimination claims were filed under (e.g., Title VII vs. Age Discrimination in Employment Act vs. Americans with Disabilities Act $[\mathrm{ADA}]$ ). Thus, the AO data cannot be used to study representation in Title VII claims prior to the mid-1990s. Overcoming these data limitations required reviewing litigation files for closed cases coded "job discrimination" by the AO. Such files are maintained in 14 National Archives and Records Administration (NARA) facilities across the United States. We drew a random sample of 1,000 such cases that were filed, from 1981 to 2000, in the Northern and Eastern Districts of California. ${ }^{4}$ Our sample ends in 2000 because

4. Using the Federal Court Cases: Integrated Data Base, maintained by the Interuniversity Consortium for Political and Social Research (ICPSR), we created a file containing only cases filed 
at the time we collected the data, after the year 2000 we encountered a significant number of case files that had not yet been moved from on-site storage in the federal courthouses to storage in the NARA.

Our decision to limit the study to two districts, with records housed in a single storage facility, was a simple function of resource limitations: the litigation files had to be reviewed on site at the NARA facility where they are maintained in storage. We acknowledge that we cannot make inferences about the nation as a whole. Nevertheless, we highlight that virtually all studies of litigation are similarly limited because the work of the American court system, and the maintenance of its records, are massively decentralized. Accordingly, the vast majority of scholarship on adjudicatory activity in America has been based on the study of activity within particular states, cities, judicial districts, and even legal services providers (e.g., Fusco et al. 1979 [Chicago]; MacCoun et al. 1988 [New Jersey]; Schwab and Eisenberg 1988 [Central District of California]; Seron et al. 2001 [New York Ciry]; Krizzer 2004 [Wisconsin]; Pardo 2009 [Western District of Washington]; Blasi and Doherty 2010 [California]; Greiner and Pattanayack 2012 [Harvard Law School legal services clinic]). Social scientific knowledge about litigation has thus been built up incrementally from many geographically limited studies, and our research contributes to that vein of work. By comparison to the studies just cited, the two districts we study govern a quite large population, exceeding 12 million people in about the midpoint of our series. 5

The litigation files were reviewed on site at the NARA facility in San Bruno, California, where they are housed. Each complaint was read in full. We recorded the statute(s) sued upon, whether the plaintiff was represented, and a battery of other variables described below. Our sample contained 659 complaints with Title VII claims. These complaints contained 416 claims of job discrimination based on race, 347 on gender, 125 on national origin, and 26 on religion. A single complaint can assert Title VII claims predicated on multiple bases of discrimination, such as race and gender. Table 1 lists the number of complaints contained in the random sample of 1,000 cases that asserted claims under Title VII and various other federal statutes. The total number of complaints sums to more than 1,000 because a single complaint can contain claims under multiple statutes. ${ }^{6}$

Alongside our Title VII cases, these data contain a set of federal job discrimination cases not affected by the CRA of 1991's new damages and jury trial provisions. This

from 1981 to 2000 in the Northern and Eastern Districts of California that were coded 442 for nature of suit ("job discrimination") and randomly drew 1,000 cases from the file using Stata's "sample" command.

5. According to the 1990 census, the populations of the counties constituting the Northern and Eastern Districts of California totaled 12,034,403.

6. Eighty-nine case files lacked codable complaints because (1) a case was removed to another federal district and the case file was taken there; (2) there was only a state job discrimination claim, and it was in federal court on the basis of diversity jurisdiction; or (3) in a small number of cases, employees at the storage facility reported that they could not locate the file. 
Table 1. Number of Employment Discrimination Complaints by Federal Statute

\begin{tabular}{|c|c|}
\hline Complaints & Statute \\
\hline 659 & Title VII of the Civil Rights Act of 1964 \\
\hline 68 & $\begin{array}{l}\text { Civil Rights Act of } 1866 \text { ( } 442 \text { U.S.C. } \$ 1981 \text { ), prohibiting interference with a person's } \\
\text { right to "make and enforce contracts" that "is enjoyed by white citizens," which was } \\
\text { interpreted in the early } 1970 \text { s to prohibit race discrimination in private employment } \\
\text { (e.g., Sanders v. Dobbs Houses, Inc., } 431 \text { F.2d } 1097 \text { [5th Cir. 1970]; Waters v. Wisconsin } \\
\text { Steel Workers, } 427 \text { F.2d } 476 \text { [7th Cir. 1970]) }\end{array}$ \\
\hline 80 & $\begin{array}{l}\text { Civil Rights Act of } 1871 \text { ( } 42 \text { U.S.C. } \$ 1983 \text { ), prohibiting violation of federal rights by } \\
\text { state actors, which supports some claims of discrimination against governmental } \\
\text { employers }\end{array}$ \\
\hline 11 & Equal Pay Act of 1963, prohibiting gender-based wage discrimination \\
\hline 161 & Age Discrimination in Employment Act of 1967 \\
\hline 45 & $\begin{array}{l}\text { Rehabilitation Act of } 1973 \text {, prohibiting employment discrimination based on disability } \\
\text { by the federal government and federal contractors }\end{array}$ \\
\hline 190 & Americans with Disabilities Act of 1990 \\
\hline
\end{tabular}

Source-1,000 random draws of cases from the Federal Court Cases: Integrated Database (ICPSR no. 8429), subset to cases coded "job discrimination" between 1981 and 2000 in the Northern and Eastern Districts of California.

Note.-The total number of complaints sums to more than 1,000 because a single complaint can contain claims under multiple statutes.

comparison group will provide some important additional leverage in our analysis. The enforcement provisions of the Civil Rights Acts of 1866 and 1871, the Age Discrimination in Employment Act, and the Equal Pay Act were not affected by the CRA of 1991.

There were a total of 256 complaints asserting such claims in our data. To the extent that passage of the CRA of 1991 was followed by an increase in the likelihood of Title VII plaintiffs securing representation, this comparison set of cases will allow us to assess whether comparable effects occurred in federal job discrimination statutes not affected by the CRA of 1991. If so, this would suggest the possibility that some factor other than the CRA of 1991 brought about a post-CRA of 1991 increase in representation in job discrimination claims in general, regardless of incentives under particular statutes.

We do not include disability cases in our comparison group. The Rehabilitation Act and the ADA incorporate Title VII's enforcement provisions by reference, and the ADA came into effect only in 1991. Because disability claims were importantly affected by the CRA of 1991 and ADA claims came into existence only at about the time of the CRA of 1991 's passage, they cannot be included in the group of claims unaffected by the CRA of 1991.

In figure 2 we present a raw count of the total number of Title VII suits filed per year in our sample, along with the count broken down separately for represented and pro se plaintiffs. The number of such suits increased significantly starting in the early 1990s. That growth was predominantly accounted for by growth among represented plaintiffs. In the late $1980 \mathrm{~s}$ and early 1990s, there were about the same number of represented and pro se plaintiffs. In the early $1990 \mathrm{~s}$, both began to increase, with represented plaintiffs 


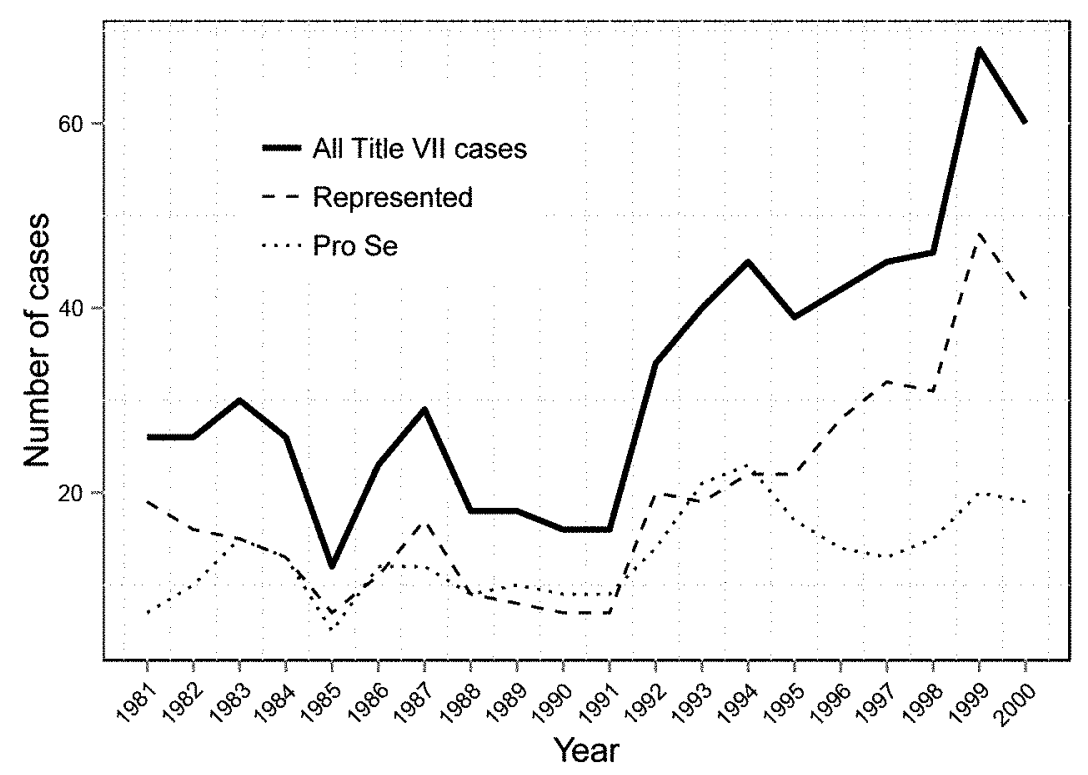

Figure 2. Number of Title VII suits per year. Source: 659 cases of 1,000 random sample of the Federal Court Cases: Integrated Database (ICPSR no. 8429), subset to cases coded "job discrimination" between 1981 and 2000 in the Northern and Eastern Districts of California. The dashed line represents cases with a plaintiff that was represented by an attorney. The dotted line represents cases with a plaintiff that filed pro se.

increasing at a somewhat higher rate; after several years, however, the separation between pro se and represented plaintiffs widened markedly, with pro se plateauing and represented plaintiffs continuing to climb.

\section{A. Longitudinal Trends in Proportion of Plaintiffs Represented}

In our empirical analysis we focus on explaining change over time in the likelihood that plaintiffs were represented. Another measurement approach would be to have as the dependent variable a count of represented plaintiffs within some unit of time. This would allow assessment of whether the CRA of 1991 increased the absolute number of represented Title VII filings. We do not add this to our analysis because we have insufficient data, which cover only 20 years. Twenty annual counts, or 40 biannual counts, would yield little data for analysis, and the data in the early years are too sparse to cut into smaller units of time. Disaggregating the data into separate models for different claim types, and controlling for important case characteristics, would be more than such data could plausibly bear. By exploiting the granularity of our case-level data and estimating the probability of representation with that unit of analysis, we greatly increase the statistical power of the models presented below, and we are able to probe the data more carefully by disaggregating modes into distinctive claim types and incorporating important 


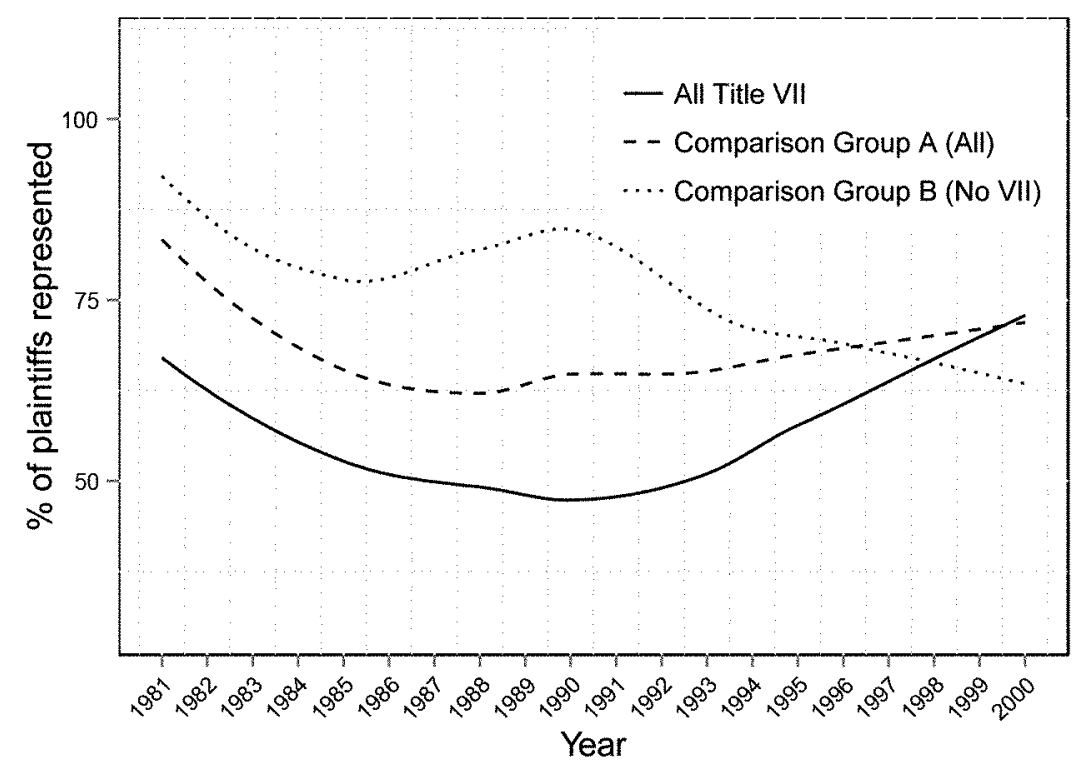

Figure 3. Locally weighted scatter plot smoothing (loess) curves estimating the annual percentage of federal employment discrimination lawsuits with a plaintiff that was repre sented by an attorney. Source: 659 cases of 1,000 random sample of the Federal Court Cases: Integrated Database (ICPSR no. 8429), subset to cases coded "job discrimination" between 1981 and 2000 in the Northern and Eastern Districts of California. Bandwidth = $80 \%$.

case-level controls. We note, however, that inferences about the absolute number of represented plaintiffs can be made. If we find that there was a statistically significant and material increase in the probability of representation at the individual case level, in combination with the obvious postintervention growth in the number of cases depicted in figure 1, it will be evident that there was an increase in the number of represented cases associated with the heightened probability of representation.

In figure 3 we present locally weighted least squares (loess) curves fit through the annual percentage of cases in which the plaintiff was represented by counsel in Title VII cases and in our comparison group. The loess curves provide a very broad sense of the longitudinal patterns in the data. ${ }^{7}$ The solid line in figure 3 indicates that the predicted values of the proportion of Title VII plaintiffs represented by counsel in our sample declined from $67 \%$ in 1981 to $50 \%$ in 1987; it ranged between $50 \%$ and $47 \%$ from 1987 to 1992 ; and from 1992 to 2000 , it rose by 24 percentage points, to $73 \%$ represented.

7. The plots show loess curves with $80 \%$ bandwidth. 
The dotted loess curve represents the percentage of plaintiffs that were represented by an attorney in comparison group complaints (labeled comparison group A). Until the very end of the series, the predicted values of representation are considerably higher in this group than for Tirle VII claims. It declined from $83 \%$ in 1981 to $62 \%$ in 1987 ; it ranged between $62 \%$ and $65 \%$ from 1987 to 1992; and from 1992 to 2000 , it rose by 7 percentage points, to $72 \%$ represented. We are mindful of the possibility that where comparison group claims are litigated jointly with Title VII claims, there may be spillover effects whereby, from the standpoint of prospective counsel, the expected value of comparison group claims is influenced by the presence of Title VII claims in the same suit. The CRA of 1991's increase in the expected value of Title VII claims may have affected the attractiveness to counsel of post-CRA of 1991 comparison group claims with cofiled Title VII claims. The dashed loess curve in figure 3 drops complaints from the comparison group with concurrently filed Title VII claims (labeled comparison group B). In this set of cases, the downward trajectory in the proportion represented does not change in the early 1990s; from 1992 to 2000 , it declined by 15 percentage points, to $63 \%$ represented. In our statistical models of representation in comparison group claims below, we will be able to control for the presence of concurrent claims under other job discrimination statutes, including Title VII.

\section{B. Change-Point Models}

Because loess curves smooth over sharp disjunctures in the data, they are not useful for identifying break points. When performing statistical tests to evaluate whether there are structural breaks in a longitudinal series, there are two basic and distinct approaches. First, change-point methods are agnostic about the existence or location of a break in the series and rely only on patterns in the data, with no structure being imposed on the data by the researcher. In the second approach, the researcher relies on theory and knowledge of historical events to impose temporal structure in the statistical model and thereby to test hypotheses with time variables incorporated into it. The first approach alone risks being atheoretical and structureless; the second approach alone risks imposing more structure on the data than is warranted (Wawro and Katznelson 2014). In our analysis, we combine the two approaches, seeking to leverage the advantages and obviate the weaknesses of each. With the first approach we assess whether the raw data reveal a structural break in the proportion of plaintiffs represented by counsel in the time window in which we anticipate effects of the CRA of 1991. With the second approach we assess whether variables modeling our anticipated cut point are statistically and substantively significant in a fully specified statistical model.

To analyze structural breaks in the raw data, we use a combination of two methods. Barry and Hartigan (1993) develop a Bayesian model that computes probabilities that there was a structural break in a series for each time interval in the data. Bai and Perron $(1998,2003)$ use regression to identify break points in a series and to calculate confidence intervals around it. Before we present the results, it is important to establish rea- 
sonable expectations about when to expect a break in the series caused by the CRA of 1991 , if one exists.

The CRA of 1991 applied to alleged discriminatory acts occurring on or after the law's effective date of November 21, 1991 (Taylor 1994). Prior to filing a Title VII case in federal court, plaintiffs must first file an administrative charge with the EEOC. The statute of limitations for a Title VII charge in California is 300 days. It is not possible to know what fraction of claims are filed very close in time to the events sued upon and what fraction are filed just before the statute of limitations expires. After an EEOC charge is filed, the EEOC investigates the claim, and upon concluding its investigation, it issues a finding of whether there is "probable cause" to believe that illegal discrimination occurred. When it does so, it also issues a "right-to-sue" letter (regardless of the direction of the probable cause finding). After a claim has been before the EEOC for 180 days without resolution, a claimant is entitled, if it so requests, to receive a right-to-sue letter and terminate the administrative process. In 1992, the average length of time the EEOC took to process a charge through to issuance of a right-to-sue letter-including both claims in which the EEOC issued a finding and claims removed from the EEOC process after 180 days and prior to issuance of a finding - was 366 days (General Accounting Office 1999, 9). After a right-to-sue letter is issued, the claimant has 90 days to file a lawsuit in federal court.

On the basis of the assumption that cases spent an average number of days in the EEOC administrative process, we can estimate the lower and upper bounds of when alleged Tile VII violations occurring in December 1991 (the month following passage) would register as federal court filings. If EEOC charges were filed sometime in December 1991, the claim spent the average 366 days before the EEOC, and litigation was filed within a week of issuance of the EEOC right-to-sue letter, the lawsuit filing would occur in the range of December 1992 to January 1993. If EEOC charges were filed in the last week of the 300-day statute of limitations period, the claim spent the average 366 days before the EEOC, and litigation was filed in the last week of the 90-day window following issuance of the EEOC right-to-sue letter, the filing would occur in the range of December 1993 to January 1994. We believe that the upper bound is more realistic given that lawyers balancing portfolios of cases are more likely to focus on deadlines than to act at the earliest possible opportunity. The upper-bound prediction thus would anticipate a change in representation near the start of 1994.

Figure $4 A$ represents both the Barry-Hartigan and the Bai-Perron change-point analyses run on the mean annual proportion of plaintiffs represented in Title VII claims. The top portion of the graph depicts the posterior probability of representation derived from the Barry-Hartigan model. It declined in the first several years of the series, was stable from 1983 to 1994 , rose sharply from 1994 to 1996 , and roughly stabilized again from 1996 through 2000. The lower panel of the figure represents the posterior probability of a change point in each year. That probability moves in a very low range from 1983 to 1993; it then rises sharply from 1993 to 1995 , where it peaks; it then returns in 1996 roughly to its $1983-93$ level, where it remains through 2000 . The dark vertical dotted line 

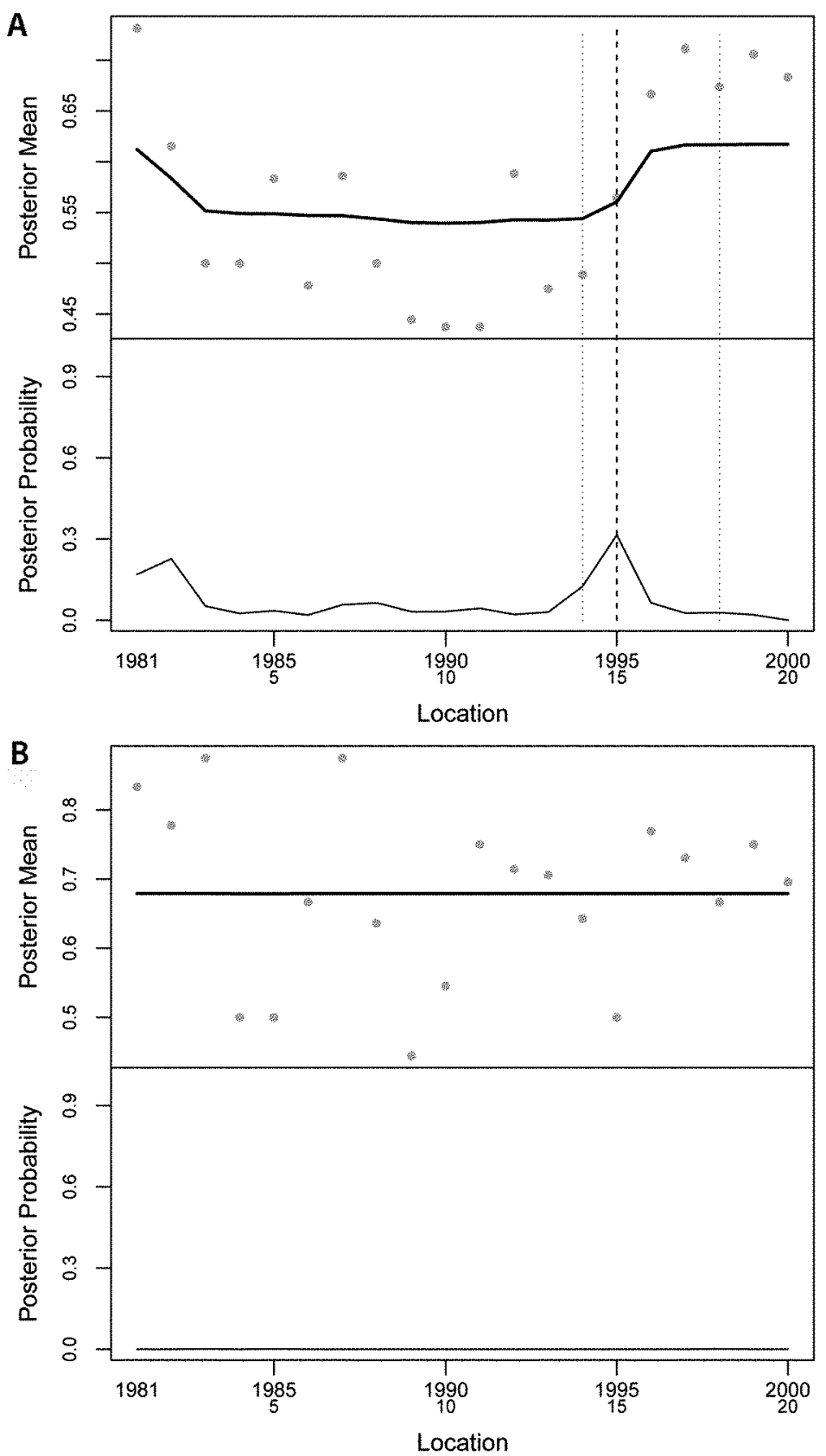

Figure 4. Change-point models of representation for Title VII cases (panel A) and nonTitle VII employment discrimination cases (panel $B$ ). The upper plot in both panels depicts the posterior probability of representation by year and the lower plot in both panels depicts the posterior probability of a change point in any given year derived from the Barry-Hartigan algorithm. The vertical dashed lines depict the change point (1995) and the vertical dotted lines depict the 95\% confidence interval (1994 and 1998) identified using the Bai-Perron algorithm. 
is the change point identified by the Bai-Perron method. The Bai-Perron method identifies 1995 as the most probable break point in the series (like the Barry-Hartigan model), with 95\% confidence intervals at 1994 and 1998. The 1994 lower bound in the Bai-Perron model coincides with the year the Barry-Hartigan model detects the first sharp jump in probability of representation after a decade of relative stability.

The change-point models thus identify a break point in the series of representation roughly coincident with the upper bound suggested by the scenario in which claims arising in December 1991 were filed with the EEOC late in their statute of limitations period, spent a year in the EEOC, and then were filed in federal court late in their 90-day window, in the range of December 1993 to January 1994.

Figure $4 B$ represents the structural break analyses run on the mean annual proportion of plaintiffs represented in our comparison group of 247 federal job discrimination complaints containing claims not affected by the CRA of 1991. The top portion of the graph indicates that the probability of representation derived from the Barry-Hartigan model did not change over the 20-year series. The bottom portion indicates that the probability of a break point in each year was essentially constant at a very low level. The Bai-Perron model was also unable to identify any meaningful break point in the series. Whatever caused the sharp upward shift in Tirle VII representation beginning around 1994 did not operate on these comparison group claims. Still, these structural break analyses cannot rule out the possibility that some other factor in the early 1990s, distinctively associated with Title VII claims, was the real cause of the growth in Title VII representation while not affecting the comparison group. In order to investigate representation in Title VII claims further, we turn to statistical models that allow incorporation of controls for a variety of potentially important factors.

\section{Model Specification}

We use logistic regression to test the effect of the CRA of 1991 on representation by counsel, which is our dependent variable. In this modeling strategy, we explicitly model a change in representation with independent variables measuring a predicted break effectuated by the CRA of 1991. Here, we impose the location of the temporal break based on the theory we seek to test and on rules governing the timing of Title VII litigation. As discussed, the 1994 break point is the outer bound of the time in which claims based on discriminatory acts in December 1991 would reach federal court if lawyers filed near relevant deadlines. It has been preliminarily validated by our change-point analyses.

We include three time variables:

1. Time is a linear annual time trend variable:

$$
\begin{gathered}
\text { Time }=\text { Year }-1993, \\
\{\text { Time } \in \mathbb{Z} \mid-13 \leq \text { Time } \leq 7\} .
\end{gathered}
$$


This variable is necessary to ensure that any significant increase in the probability of representation after the CRA of 1991 is not actually a simple function of a broad time trend toward increasing representation by counsel that had nothing to do with the CRA of 1991.

2. CRA captures the 1994 break point:

$$
C R A= \begin{cases}0 & \text { when Year }<1994 \\ 1 & \text { when Year } \geq 1994 .\end{cases}
$$

This dummy variable is one way of detecting whether there was an increase in the probability of representation starting in 1994. It models the act as taking its full effect starting in 1994, in a single stepwise transition, when the value of the variable switches from 0 to 1 .

3. CRA $\times$ Time is an interaction of the CRA dummy and the linear time trend and is another way of detecting an increase in the probability of representation starting in 1994, but with a different functional form. In contrast to CRA, this variable takes the value of 0 prior to 1994 but then has a linear growth pattern starting in 1994. It models the CRA of 1991 as having triggered an incremental pattern of growth in the probability of representation starting in 1994.

We adopt a flexible model specification that can detect either a single stepwise increase in mean representation occurring at a discrete break point (the CRA dummy) or an incremental growth pattern beginning at that break point ( $\mathrm{CRA} \times$ Time) because we lack a firm theoretical basis to impose only one functional form in the model. On the one hand, it is possible that diffusion of information about the new law to prospective plaintiffs, and corresponding effects on their claiming behavior and efforts to secure counsel, were fully realized at a discrete point in time. Likewise, it is possible that the existing plaintiffs' job discrimination bar had sufficient unutilized capacity to very rapidly and fully absorb new opportunities for litigation. In this scenario, we would predict a single stepwise increase to a new mean level of representation following passage of the law. This would follow the functional form of the CRA dummy.

On the other hand, it is possible that the diffusion of information to prospective plaintiffs, and corresponding effects on their claiming behavior and efforts to secure counsel, were more gradual. Likewise, it is possible that there was an incremental process of growth of the bar needed to litigate the new claims. In this scenario, we would predict an incremental growth in representation following passage of the law. This would follow the functional form of CRA $\times$ Time.

The social and economic processes involved in the diffusion of information to the plaintiff population, the timing of its influence on their claiming behavior, and the speed with which legal labor markets grow are complex. We are aware of no literature that would allow us to make strong predictions in favor of either a single stepwise change or an 
incremental growth scenario, to the exclusion of the other. Accordingly, rather than imposing one versus the other functional form on the data, we let the data speak for themselves and allow our interaction setup to adjudicate between theoretically plausible functional forms of the relationship we test for.

We include a battery of controls that may be associated with a plaintiff's ability to secure counsel, as follows:

- dummy variables indicating the grounds of discrimination alleged, which are the nonexclusive categories of race, national origin, gender, religion, age, and disability; - dummy variables indicating the nature of the discrimination alleged, which are the nonexclusive categories of failure to hire, termination, failure to promote, demotion, pay, hostile environment, retaliation, or a disparate impact claim;

- dummy variables indicating whether the defendant was a federal governmental entity, a state governmental entity, or a private entity, with private defendants left out as the reference category;

- dummy variables indicating concurrent claims under other statutes.

Finally, we control for judicial ideology. It has been shown that the ideology of appellate judges is an important factor contributing to the doctrine they create in civil rights cases, with greater degrees of liberalism associated with a more pro-plaintiff orientation (Segal and Spaeth 2002; Sunstein, Schkade, and Ellman 2006; Moyer and Tankersley 2012). Thus, we incorporate into our model measures of both Supreme Court and Ninth Circuit ideology. We model Supreme Court ideology with median Supreme Court justice ideology scores recently developed by Cameron and Park (2009); we observe similar results (clear statistical insignificance) in alternative specifications using two other widely used measures of Supreme Court ideology. ${ }^{8}$ To model Ninth Circuit ideology, we followed Giles, Hettinger, and Peppers $(2001,2002)$ in relying on a combination of appointing presidents' and senators' common space NOMINATE scores, and we compute Ninth Circuit ideology as the mean score of active judges on the circuit.' While one might anticipate that incorporating both Supreme Court and Ninth Circuit ideology into a model could raise problems of collinearity, this is not the case. The measures have a correlation coefficient of only .29 , and each variable's clear insignificance in all models (below) remains when the other is dropped. We lag both ideology measures 1 year to allow movement in judicial ideology to affect doctrine and lawyer perceptions

8. Segal and Cover (1989) scores and Martin and Quinn (2002) scores also proved statistically insignificant by a wide margin, and the choice of a measure did not materially affect other variables in the models.

9. While the median is appropriate for the Supreme Court, where the full court hears cases, the mean is appropriate for the Court of Appeals, where three judges are randomly drawn from the full circuit to hear cases. If the median were used for the circuit, the value of the variable may not vary on membership changes that in fact influence the ideological distribution of randomly drawn panels. 
of the expected value of lawsuits. In alternative specifications we also incorporated a variable measuring the mean common space NOMINATE scores (computed as described above) for active judges at the district court level, and this too proved insignificant. Summary statistics are presented in table 2 .

Recall that the CRA of 1991 was precipitated by, and overruled, a series of Supreme Court decisions issued between 1989 and 1991 that were to the disadvantage of Title VII plaintiffs. It is important to stress that to the extent that the CRA of 1991's override of these decisions - as distinguished from its new damages and jury trial provisionsenhanced the expected value of Title VII claims, the effect was to restore the law to its condition in April 1989, before the first of the overridden decisions were issued. The year 1989 is near the nadir of Title VII representation in the loess plot in figure 3, and it is in the midst of the long stable lower bound in the proportion of Tirle VII plaintiffs represented in the Barry-Hartigan model (see the upper quadrant of fig. $4 A$ ). Accordingly, restoration of substantive Tirle VII doctrine to its state in 1989 cannot explain the subsequent jump in Title VII representation to levels not seen since the early 1980s.

\section{MODEL AND FINDINGS}

We estimate case-level logit models on representation:

$$
\operatorname{Pr}\left(y_{p}\right)=\operatorname{logit}^{-1}\left(\beta_{1} \mathrm{CRA}_{p}+\beta_{2} \text { Time }_{p}+\beta_{3} \mathrm{CRA} \times \text { Time }_{p}+\beta_{4} W_{p}\right) .
$$

Our outcome variable $y_{p}$ is a binary variable that equals 1 when plaintiff $p$ is represented and 0 otherwise. In our interaction setup the coefficient on Time reflects the effect of the linear time trend before 1994 (when CRA =0), causing the interaction term to drop out of the equation. For the years beginning with 1994 (when CRA $=1$ ), the linear time trend is captured by the sum of the coefficients on Time and CRA $\times$ Time (see Brambor, Clark, and Golder [2006], discussing interpretation of interaction models). Finally, $W$ represents a vector of nontime controls described above.

Column 1 in table 3 presents a parsimonious model run on Title VII cases with only our time variables. ${ }^{10}$ Time reflects no significant time trend in plaintiffs' likelihood of representation for the 1981-93 period, and CRA is statistically insignificant as well. The variable CRA $\times$ Time indicates a statistically significant positive time trend in the probability of representation for the 1994-2000 period $(p=.007)$. In order to assess the magnitude of the effect, we generate predicted probabilities for our time coefficients. ${ }^{11}$

10. Eighteen of our 659 Title VII cases and nine of our 256 comparison group cases are not used in the models presented because the EEOC represented the plaintiffs, and there is no reason to believe that the EEOC's selection of cases to prosecute would be influenced by the economic value of claims.

11. We can solve for the probability of representation using the logit function by exponentiating the logit of the underlying probability $\pi_{p}$ such that if $\log i \mathrm{t}\left(\pi_{p}\right)=\eta_{p}$, then $\pi_{p}=e^{\eta_{p}} /\left(1+e^{\eta_{p}}\right)$. 
Table 2. Summary Statistics of Variables Affecting Representation in Title VII Cases

\begin{tabular}{|c|c|c|c|c|}
\hline Variable & Mean & $\begin{array}{l}\text { Standard } \\
\text { Deviation }\end{array}$ & Minimum & Maximum \\
\hline Representation & .60 & .49 & 0 & 1 \\
\hline Request for counsel & .26 & .44 & 0 & 1 \\
\hline CRA & .64 & .48 & 0 & 1 \\
\hline Time & 1.47 & 5.98 & -13 & 7 \\
\hline $\mathrm{CRA} \times$ Time & 3.48 & 3.35 & 0 & 7 \\
\hline Supreme Court ideology & .29 & .04 & .17 & .31 \\
\hline Ninth Circuit ideology & -.03 & .07 & -.15 & .09 \\
\hline State defendant & .27 & .44 & 0 & 1 \\
\hline Federal defendant & .22 & .41 & 0 & 1 \\
\hline Private defendant & .51 & .50 & 0 & 1 \\
\hline Race claim & .63 & .48 & 0 & 1 \\
\hline National origin claim & .19 & .39 & 0 & 1 \\
\hline Gender claim & .53 & .50 & 0 & 1 \\
\hline Religion claim & .04 & .20 & 0 & 1 \\
\hline Retaliation claim & .28 & .45 & 0 & 1 \\
\hline Termination allegation & .54 & .50 & 0 & 1 \\
\hline Hiring allegation & .08 & .27 & 0 & 1 \\
\hline Promotion allegation & .26 & .44 & 0 & 1 \\
\hline Demotion allegation & .07 & .25 & 0 & 1 \\
\hline Pay allegation & .10 & .30 & 0 & 1 \\
\hline Harassment allegation & .39 & .49 & 0 & 1 \\
\hline
\end{tabular}

Harassment allegation

Source.-Federal Court Cases: Integrated Database (ICPSR no. 8429), subset to cases coded "job discrimination" between 1981 and 2000 in the Northern and Eastern Districts of California.

Note-Supreme Court ideology measures are based on Cameron and Park (2009). Ninth Circuit ideology measures are based on Giles et al. (2002).

The sum of the coefficients on Time and CRA $\times$ Time reflects that the probability of representation increased by an average of $2.6[0.5,5.6]$ percentage points per year, for a total increase of 18 percentage points from 1994 to $2000 .^{12}$

Column 2 in table 3 is the full model run on Title VII cases. Time reflects a significant negative time trend in the likelihood of plaintiffs being represented by counsel for the 1981-93 period $(p=.08)$. In terms of predicted probabilities, with other variables in the model held constant, the coefficient on Time indicates a $-1.74[-4.1,0.7]$ percentage point decline in the probability of representation per year between 1981 and 1993 , for a total decline of 19 percentage points. The probability of representation declined from $67 \%$ in 1981 to $48 \%$ in $1993 .{ }^{13}$

12. Confidence intervals represent $95 \%$ of estimated predicted probabilities on 1,000 bootstrap samples of the data.

13. While the negative coefficient on Time is clearly statistically significant, the associated predicted probability has a $95 \%$ confidence interval that marginally crosses zero. The confidence interval does not cross zero at the $94 \%$ confidence level. 
The variable CRA is statistically insignificant. The variable CRA $\times$ Time indicates that the negative time trend reflected in Time with respect to the probability of representation in the 1981-93 period was reversed and became positive and significant ( $p=.012$ ) for the 1994-2000 period. The magnitude of the effect is significantly larger than in the parsimonious model. The sum of the coefficients on Time and CRA $\times$ Time reflects that, net of the effects of the other variables, the probability of representation increased by $5[1.6,12]$ percentage points per year between 1994 and 2000, for a total increase of 35 percentage points. The predicted probability of representation grew from $48 \%$ in 1993 to $83 \%$ in 2000 . We note that comparing to the 1993 baseline may actually understate the influence of the CRA of 1991, since the long-run decline in representation over the decade leading up to the act may have continued its downward trajectory in the absence of the act.

A number of the control variables are statistically significant and substantively important. The dummy variables reflecting the presence of race and national origin discrimination claims are both statistically and substantively significant. The assertion of race and national origin claims is associated with a reduction in the probability of representation by $-24.4[-34.0,-15.0]$ and $-20.5[-31.0,-8.0]$ percentage points, respectively, holding constant all other variables at their mean value. Plaintiffs suing federal defendants are substantially less likely to be represented by counsel, and plaintiffs alleging discriminatory harassment are substantially more likely to be represented. The other variables measuring case facts are insignificant.

Judicial ideology, measured at both the Supreme Court and the Court of Appeals levels, is also insignificant. Since we are especially interested in explaining the relatively strong increase in the probability of representation around 1994, looking for causes in the 1991-94 window, we further note that, even aside from the null findings in the statistical model, movement in judicial preferences does not seem a likely explanation for growing representation. During this window of time, the Supreme Court's median justice did not change; the Ninth Circuit experienced one Bush I and one Clinton appointment, with no exits from active status; and the Northern and Eastern Districts, when new appointments and exits from the bench are netted out, experienced an increase of one Republican judge. ${ }^{14}$

Column 3 of table 3 is the full model run separately on race and national origin claims, and column 4 is the full model run separately on gender claims. The patterns in post1993 representation across the two types of Title VII claims are consistent with the pooled model in terms of both statistical significance and magnitude of the effects. This suggests that unobserved factors distinctively operating on one or the other major type of Title VII claim are not driving the overall post-CRA representation effects in the full model.

14. This information comes from the Federal Judicial Center Database. 
Table 3. Logit Models of Factors Affecting Representation in Title VII Cases between 1981 and 2000

\begin{tabular}{|c|c|c|c|c|}
\hline & $\begin{array}{l}\text { Parsimonious } \\
\text { (1) }\end{array}$ & $\begin{array}{l}\text { Full Model } \\
\text { (2) }\end{array}$ & $\begin{array}{l}\text { Race and } \\
\text { Origin } \\
\text { (3) }\end{array}$ & $\begin{array}{c}\text { Gender } \\
\text { Only } \\
\text { (4) }\end{array}$ \\
\hline CRA dummy & $\begin{array}{c}.17 \\
(.33)\end{array}$ & $\begin{array}{r}-.19 \\
(.42)\end{array}$ & $\begin{array}{r}-.13 \\
(.49)\end{array}$ & $\begin{array}{l}-.30 \\
(.64)\end{array}$ \\
\hline Time & $\begin{array}{c}-.04 \\
(.03)\end{array}$ & $\begin{array}{r}-.10^{*} \\
(.06)\end{array}$ & $\begin{array}{c}-.16^{* *} \\
(.07)\end{array}$ & $\begin{array}{r}-.15^{*} \\
(.09)\end{array}$ \\
\hline CRA $\times$ Time & $\begin{array}{l}.17^{* * *} \\
(.06)\end{array}$ & $\begin{array}{l}.31^{* *} \\
(.12)\end{array}$ & $\begin{array}{l}.41^{* * *} \\
(.14)\end{array}$ & $\begin{array}{l}.39^{* *} \\
(.18)\end{array}$ \\
\hline Supreme Court ideology (lagged) & & $\begin{array}{l}-.10 \\
(3.23)\end{array}$ & $\begin{array}{l}-.34 \\
(3.73)\end{array}$ & $\begin{array}{c}2.43 \\
(4.99)\end{array}$ \\
\hline Ninth Circuit ideology (lagged) & & $\begin{array}{c}3.51 \\
(2.98)\end{array}$ & $\begin{array}{c}4.81 \\
(3.43)\end{array}$ & $\begin{array}{c}5.80 \\
(4.33)\end{array}$ \\
\hline Defendant is state government & & $\begin{array}{r}-.30 \\
(.23)\end{array}$ & $\begin{array}{c}-.43 \\
(.27)\end{array}$ & $\begin{array}{r}-.50 \\
(.33)\end{array}$ \\
\hline Defendant is federal government & & $\begin{array}{c}-.50^{* *} \\
(.23)\end{array}$ & $\begin{array}{c}-.43 \\
(.27)\end{array}$ & $\begin{array}{c}-.94^{* * *} \\
(.34)\end{array}$ \\
\hline Race claim & & $\begin{array}{c}-1.06^{* * *} \\
(.21)\end{array}$ & $\begin{array}{l}-.99^{* *} \\
(.43)\end{array}$ & $\begin{array}{c}-1.03^{* * *} \\
(.29)\end{array}$ \\
\hline Origin claim & & $\begin{array}{c}-.81^{* * *} \\
(.23)\end{array}$ & $\begin{array}{c}-.81^{* * * *} \\
(.29)\end{array}$ & $\begin{array}{c}-1.03^{* * *} \\
(.38)\end{array}$ \\
\hline Gender claim & & $\begin{array}{l}-.19 \\
(.20)\end{array}$ & $\begin{array}{c}-.24 \\
(.23)\end{array}$ & \\
\hline Religion claim & & $\begin{array}{c}-.01 \\
(.46)\end{array}$ & $\begin{array}{r}-.06 \\
(.50)\end{array}$ & $\begin{array}{r}-.16 \\
(.63)\end{array}$ \\
\hline Retaliation claim & & $\begin{array}{l}.15 \\
(.21)\end{array}$ & $\begin{array}{c}.21 \\
(.25)\end{array}$ & $\begin{array}{c}.22 \\
(.29)\end{array}$ \\
\hline Disparate impact & & $\begin{array}{l}.57 \\
(.66)\end{array}$ & $\begin{array}{c}.46 \\
(.80)\end{array}$ & $\begin{array}{r}-.18 \\
(.87)\end{array}$ \\
\hline Termination allegation & & $\begin{array}{l}-.13 \\
(.20)\end{array}$ & $\begin{array}{c}.01 \\
(.25)\end{array}$ & $\begin{array}{r}-.56^{*} \\
(.29)\end{array}$ \\
\hline Hiring allegation & & $\begin{array}{l}.37 \\
(.36)\end{array}$ & $\begin{array}{c}.32 \\
(.40)\end{array}$ & $\begin{array}{c}.90 \\
(.63)\end{array}$ \\
\hline Promotion allegation & & $\begin{array}{l}.04 \\
(.22)\end{array}$ & $\begin{array}{c}.18 \\
(.26)\end{array}$ & $\begin{array}{r}-.19 \\
(.32)\end{array}$ \\
\hline Demotion allegation & & $\begin{array}{c}.30 \\
(.37)\end{array}$ & $\begin{array}{l}.84^{*} \\
(.44)\end{array}$ & $\begin{array}{r}-.36 \\
(.58)\end{array}$ \\
\hline Pay allegation & & $\begin{array}{c}.14 \\
(.30)\end{array}$ & $\begin{array}{c}.27 \\
(.33)\end{array}$ & $\begin{array}{l}-.43 \\
(.44)\end{array}$ \\
\hline Harassment allegation & & $\begin{array}{l}.62^{* * *} \\
(.20)\end{array}$ & $\begin{array}{r}.40^{*} \\
(.24)\end{array}$ & $\begin{array}{c}.32 \\
(.30)\end{array}$ \\
\hline Concurrent age allegation & & $\begin{array}{c}-.32 \\
(.26)\end{array}$ & $\begin{array}{c}-.01 \\
(.29)\end{array}$ & $\begin{array}{r}-.89^{*} \\
(.39)\end{array}$ \\
\hline Concurrent reconstruction claim & & $\begin{array}{l}1.56^{* * *} \\
(.48)\end{array}$ & $\begin{array}{l}2.07^{* * *} \\
(.57)\end{array}$ & $\begin{array}{l}1.68^{* *} \\
(.65)\end{array}$ \\
\hline Concurrent disability claim & & $\begin{array}{l}.15 \\
(.32)\end{array}$ & $\begin{array}{c}.27 \\
(.37)\end{array}$ & $\begin{array}{c}.66 \\
(.48)\end{array}$ \\
\hline
\end{tabular}


Table 3. (Continued)

\begin{tabular}{lcccc}
\hline & $\begin{array}{c}\text { Race and } \\
\text { Orsimonious } \\
\text { Intercept }\end{array}$ & $\begin{array}{c}\text { Full Model } \\
(1)\end{array}$ & $\begin{array}{c}\text { Gender } \\
\text { Only } \\
(4)\end{array}$ & $\begin{array}{c}(3) \\
N\end{array}$ \\
$L$ & -.14 & .61 & .21 & .31 \\
$\log$ & 641 & $(1.07)$ & $(1.29)$ & $(1.64)$ \\
\hline
\end{tabular}

Source.-Federal Court Cases: Integrated Database (ICPSR no. 8429), subset to cases coded "job discrimination" between 1981 and 2000 in the Northern and Eastern Districts of California.

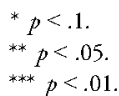

In an alternative specification (not displayed), we drop the time trend variable (Time) and the interaction term (CRA $\times$ Time) from the full model, leaving the CRA dummy as the only variable measuring time in the model. This "temporally naive" model tests only for differences in the mean probability of representation before and after the cut point, ignoring the possibility of incremental time trends. The CRA coefficient is significant ( $p$ $=.007$ ) and suggests a growth of $14[3.7,25.3]$ percentage points in the mean predicted probability of representation in the 1994-2000 period, relative to the 1981-93 period. The effects of other variables in the temporally naive model are not materially different than in the interaction model. Our interpretation of the fact that the CRA dummy becomes insignificant when Time and CRA $\times$ Time are added is that the interaction model provides a better fit to the data, picking up the fact that there was a pattern of incremental decline in representation prior to the cut point and a pattern of incremental growth after it. In addition to fitting the data better as a statistical matter, the results on Time and CRA $\times$ Time are also more consistent with the observed convex shape of Title VII representation over the period modeled (see fig. 2) as compared to the temporally naive model's limitation of the functional form of time to a single stepwise increase at a discrete point in time.

Column 1 of table 4 is the parsimonious model run on the 247 comparison cases (Reconstruction, Age Discrimination in Employment Act, and Equal Pay Act suits) with only our three time variables: Time, CRA, and CRA $\times$ Time. This initial parsimonious model does not control for whether the comparison group claims had cofiled Title VII claims. Given the growth in representation in Title VII claims during the 1994-2000 period (fig. 2), this model thus may be biased toward detecting a positive effect in representation in comparison group claims during this period due to spillover effects from cofiled Title VII claims. Nevertheless, none of the time variables are significant. There was no change in the probability of representation by counsel either from 1981 to 1993 or from 1994 to 2000, nor was there a change between the two periods.

Column 2 of table 4 adds variables reflecting the presence of a concurrent Title VII claim, an interaction of that variable with CRA, and an interaction of that interaction 
Table 4. Logit Models of Factors Affecting Representation in Title VII and Non-Title VII Cases

\begin{tabular}{|c|c|c|c|}
\hline & $\begin{array}{l}\text { Parsimonious } \\
\text { (1) }\end{array}$ & $\begin{array}{c}\text { Concurrent VII } \\
\text { (2) }\end{array}$ & $\begin{array}{l}\text { Full Model } \\
\text { (3) }\end{array}$ \\
\hline CRA dummy & $\begin{array}{l}-.21 \\
(.55)\end{array}$ & $\begin{array}{c}-.11 \\
(.80)\end{array}$ & $\begin{array}{c}-.64 \\
(.97)\end{array}$ \\
\hline Time & $\begin{array}{l}-.03 \\
(.06)\end{array}$ & $\begin{array}{c}-.02 \\
(.06)\end{array}$ & $\begin{array}{c}-.03 \\
(.10)\end{array}$ \\
\hline CRA $\times$ Time & $\begin{array}{l}.12 \\
(.11)\end{array}$ & $\begin{array}{c}-.08 \\
(.14)\end{array}$ & $\begin{array}{l}.03 \\
(.23)\end{array}$ \\
\hline Title VII claim & & $\begin{array}{c}-1.12^{* *} \\
(.45)\end{array}$ & $\begin{array}{r}-.90^{*} \\
(.51)\end{array}$ \\
\hline Title VII $\times$ CRA & & $\begin{array}{l}-.66 \\
(1.01)\end{array}$ & $\begin{array}{l}-.61 \\
(1.12)\end{array}$ \\
\hline Title VII $\times$ CRA $\times$ Time & & $\begin{array}{l}.40^{* *} \\
(.19)\end{array}$ & $\begin{array}{r}.39^{*} \\
(.21)\end{array}$ \\
\hline Supreme Court ideology (lagged) & & & $\begin{array}{c}4.66 \\
(6.71)\end{array}$ \\
\hline Ninth Circuit ideology (lagged) & & & $\begin{array}{c}1.18 \\
(4.90)\end{array}$ \\
\hline Defendant is state government & & & $\begin{array}{r}-.60 \\
(.41)\end{array}$ \\
\hline Defendant is federal government & & & $\begin{array}{c}-.69 \\
(.47)\end{array}$ \\
\hline Age discrimination claim & & & $\begin{array}{l}1.80^{* *} \\
(.91)\end{array}$ \\
\hline Reconstruction civil rights claim & & & $\begin{array}{c}.00 \\
(.91)\end{array}$ \\
\hline Equal Pay Act claim & & & $\begin{array}{l}-.87 \\
(1.22)\end{array}$ \\
\hline Retaliation allegation (non-Title VII) & & & $\begin{array}{c}.28 \\
(.77)\end{array}$ \\
\hline Termination allegation & & & $\begin{array}{l}.24 \\
(.38)\end{array}$ \\
\hline Hiring allegation & & & $\begin{array}{c}.26 \\
(.61)\end{array}$ \\
\hline Promotion allegation & & & $\begin{array}{l}-.08 \\
(.44)\end{array}$ \\
\hline Demotion allegation & & & $\begin{array}{l}.33 \\
(.56)\end{array}$ \\
\hline Pay allegation & & & $\begin{array}{c}.14 \\
(.55)\end{array}$ \\
\hline Harassment allegation (non-Title VII) & & & $\begin{array}{l}.20 \\
(.46)\end{array}$ \\
\hline Disability claim & & & $\begin{array}{c}.49 \\
(.51)\end{array}$ \\
\hline Intercept & $\begin{array}{c}.54 \\
(.34)\end{array}$ & $\begin{array}{l}1.30^{* * * *} \\
(.48)\end{array}$ & $\begin{array}{c}1.23 \\
(2.23)\end{array}$ \\
\hline $\begin{array}{l}N \\
\log L\end{array}$ & $\begin{array}{l}247 \\
-143.60\end{array}$ & $\begin{array}{l}247 \\
-129.09\end{array}$ & $\begin{array}{l}247 \\
-69.72\end{array}$ \\
\hline
\end{tabular}

Source.-Federal Court Cases: Integrated Database (ICPSR no. 8429), subset to cases coded "job discrimination" between 1981 and 2000 in the Northern and Eastern Districts of California.

${ }^{*} p<.1$.

** $p<.05$.

$* * * *<<.01$ 
with Time. Title VII claim $\times$ CRA takes a value of 1 for complaints with cofiled Title VII claims starting in 1994; it takes the value 0 orherwise. Title VII claim $\times$ CRA $\times$ Time takes a value of 1 for complaints with cofiled Title VII claims in 1994 and increases by one unit each year until 2000; it takes the value 0 otherwise. In this model, again, none of the time variables for our comparison cases (Time, CRA, and CRA $\times$ Time) are significantly associated with representation. Title VII claim is significant and negative, indicating that from 1981 to 1993 , comparison group plaintiffs that filed concurrent Title VII claims were less likely to be represented. Tirle VII daim $\times$ CRA $\times$ Time is significant and positive, indicating that over the 1994-2000 period, the probability of representation for this group increased.

Column 3 of table 4 adds control variables to our model run on the 247 comparison cases. The time variables (Time, CRA, and CRA $\times$ Time) remain insignificant, reflecting the absence of any time trend in the probability of representation in our comparison group claims. The variables measuring cofiled Title VII claims remain significant, though only at the .1 level, with the same signs. From 1981 to 1993, comparison group plaintiffs that filed concurrent Title VII claims were less likely to be represented, and in the 19942000 period, their level of representation increased.

Finally, in an alternative specification of the comparison group model, we additionally dropped Time and CRA $\times$ Time from the full model, keeping the CRA dummy as the only time variable predicting representation in comparison group claims. This model is equivalent to what we called the temporally naive model above, but here it is run on comparison group claims. The CRA dummy was insignificant. ${ }^{15}$ Thus, all our regression models of representation in the comparison group claims - parsimonious and full, with and without controls for cofiled Title VII claims, temporally naive and with time trend interactions - consistently reflect no change in the probability of representation in the 1994-2000 period. These null results are consistent with the null results of the changepoint models run on comparison group claims. The growth in representation in Title VII claims in the 1994-2000 period did not reflect a more general growth in representation in federal job discrimination claims. It was a distinctive development in the domain of Title VII.

\section{CONCLUSION}

We conclude that the CRA of 1991, by increasing the expected value of Title VII lawsuits, had the effect of materially increasing the probability that plaintiffs would be represented by counsel. This post-CRA trend constituted the reversal of a trend in the opposite direction over the decade prior to the act. The magnitude of the increase in representation was substantial: our model reflects that between 1994 and 2000, it grew by

15. This is true both with and without Title VII claim and its interactions with CRA and CRA $\times$ Time. 
35 percentage points, from $48 \%$ to $83 \%$. In addition to finding this positive representation effect when all Title VII claims are pooled, the effect was evident in models focusing only on race and national origin claims and focusing only on gender claims, showing that our results are not driven by one particular claim type. Moreover, our analysis of comparison group claims - federal job discrimination actions brought under statutes that did not receive the new incentives conferred by the CRA of 1991 — showed that they did not experience a post-CRA increase in the probability of representation. Thus, the positive representation effects we detect in Title VII claims following the CRA of 1991 are not generally observed in federal job discrimination litigation; they are concentrated in the statute whose enforcement provisions the CRA of 1991 amended-Title VII.

Whether and how effectively Congress can increase representation by statutorily manipulating the expected value of claims is a question of considerable consequence. American legislators' reliance on private enforcement regimes for policy implementation is widespread, cutring across virtually every area of regulatory policy in the modern American state. Where a regulatory enforcement regime depends on private lawsuits, its efficacy will hinge on the mobilization of lawyers, not just plaintiffs. No past research has attempted to assess whether and, if so, to what extent Congress can effectively determine the overall degree of attorney representation under a statute by manipulating the expected value of claims. This is a highly nonobvious empirical question, with predictions hinging on assumptions for which we lack strong theory. In Title VII litigation following the CRA of 1991, we find a substantively strong positive representation effect. Our results show that, in some circumstances, the strategy of bolstering representation by increasing the expected value of claims can be quite effective in materially raising overall levels of representation. Future work is surely needed focusing on other policy areas, time periods, and methods of affecting expected value in order to build our understanding of linkages between statutory design and attorney representation.

\section{REFERENCES}

Bai, Jushan, and Pierre Perron. 1998. "Estimating and Testing Linear Models with Multiple Structural Changes." Econornetrica 66:47-78.

- 2003. "Computation and Analysis of Multiple Structural Change Models." Joumal of Applied Econometrics 18:1-22.

Bardach, Eugene, and Robert A. Kagan. 2002. Going by the Book: The Problem of Regulatory Unreasonableness. Rev. ed. Philadelphia: Translation Publishers.

Barry, Daniel, and J. A. Hartigan. 1993. "A Bayesian Analysis for Change Point Problems." Journal of the American Statistical Assaciation 35:309-19.

Blasi, Gary L., and Joseph W. Doherty. 2010. "California Employment Discrimination Law and Its Enforcement: The Fair Employment and Housing Act at 50." Manuscript, Center for Law and Public Policy, University of California, Los Angeles, and RAND Corporation. http://ssrn.com /paper $=1596906$.

Brambor, Thomas, William Clark, and Matt Golder. 2006. "Understanding Interaction Models: Improving Empirical Analyses." Political Analysis 14:63-82. 
Burke, Thomas F. 2002. Lawyers, Lawsuits, and Legal Rights: The Battle over Litigation in American Society. Berkeley: University of California Press.

Cameron, Charles, and Jee-Kwang Park. 2009. "How Will They Vote? Predicting the Future Behavior of Supreme Court Nominees, 1937-2006." Journal of Empirical Legal Studies 6: 485-511.

Cooter, Robert D., and Daniel L. Rubinfeld. 1994. "An Economic Model of Legal Discovery." Journal of Legal Studies 23:435-63.

Cooter, Robert D., and Thomas Ulen. 2004. Law and Economics. 4th ed. Boston: Addison-Wesley.

Davies, Julie. 1997. "Federal Civil Rights Practice in the 1990's: The Dichotomy between Reality and Theory." Hastings Law Joumal 48:197-270.

Derfner, Mary Frances. 1977. "One Giant Step: The Civil Rights Attorney's Fees Awards Act of 1976." Saint Louis University Law Journal 21:441-51.

Drahozal, Christopher. 2009. "Arbitration Costs and Contingent Fee Contracts." Vanderbilt Law Review 59:729-91.

Epp, Charles R. 1998. The Rights Revolution: Lauyers, Activists, and Supreme Courts in Comparative Perspective. Chicago: University of Chicago Press.

Eskridge, William N., Jr., Phillip P. Frickey, and Elizabeth Garrett. 2001. Cases and Materials on Legislation: Statutes and the Creation of Public Policy. 3rd ed. Saint Paul, MN: West Group.

Farhang, Sean. 2009. "Congressional Mobilization of Private Litigants: Evidence from the Civil Rights Act of 1991." Journal of Empirical Legal Studies 6:1-34.

2010. The Litigation State: Public Regulation and Private Lawsuits in the U.S. Princeton, NJ: Princeton University Press.

Fiorina, Morris P. 1982. "Legislative Choice of Regulatory Forms: Legal Process or Administrative Process?" Public Choice 39:33-66.

Frymer, Paul. 2007. Black and Blue: African Americans, the Labor Movement, and the Decline of the Democratic Party. Princeton, NJ: Princeton University Press.

Fusco, Anthony J., Nancy B. Collins, and Julian R. Bimbaum. 1979. "Chicago's Eviction Court: A Tenant's Court of No Resort." Urban Law Journal 17:93-132.

Galanter, Marc. 1974. "Why the 'Haves' Come Out Ahead: Speculations on the Limits of Legal Change." Law and Society Review 9:95-160.

Galanter, Marc, and David Luban. 1993. "Poetic Justice: Punitive Damage and Legal Pluralism." American University Law Review 42:1393-1463.

General Accounting Office. 1999. Equal Employment Opportunity: Complaint Caseloads Rising, with Effects of New Regulations on Future Trends Unclear. GAO/GGD-99-128. Washington, DC: General Accounting Office.

Giles, Micheal W., Virginia A. Hettinger, and Todd Peppers. 2001. "Picking Federal Judges: A Note on Policy and Partisan Selection Agendas." Political Research Quarterly 54:623-41.

. 2002. "Measuring the Preferences of Federal Judges: Alternatives to Party of the Appointing President." Working paper, Emory University.

Goldfarb, Lewis H., et al. 2006. "Report on Contingent Fees in Class Action Litigation." Review of Litigation 25:459-96.

Govan, Reginald C. 1993. "Honorable Compromises and the Moral High Ground: The Conflict between the Rhetoric and the Content of the Civil Rights Act of 1991." Rutgers Law Review 46:1-242.

Greiner, D. James, and Cassandra Wolos Pattanayak. 2012. "Randomized Evaluation in Legal Assistance: What Difference Does Representation (Offer and Actual Use) Make?" Yale Law Journal 121:2118-2214.

Greve, Michael S. 1989. "Environmentalism and Bounty Hunting." Public Interest 97:15-29. 
Hickox, Stacy A. 2010. "Ensuring Enforceability and Faimess in the Arbitration of Employment Disputes." Widener Law Revieu 16:101-74.

Johnson, Earl, Jr. 1980. "Lawyers' Choice: A Theoretical Appraisal of Litigation Investment Decisions." Law and Society Review 15:567-610.

Kagan, Robert A. 2001. Adversarial Legalism: The American Way of Law. Cambridge, MA: Harvard University Press.

Kornhauser, Lewis A., and Richard L. Revesz. 1994. "Multidefendant Settlements: The Impact of Joint and Several Liability." Journal of Legal Studies 23 (1): 41-76.

Kritzer, Herbert M. 2001. "Lawyer Fees and Lawyer Behavior in Litigation: What Does the Empirical Evidence Really Say?” Texas Law Review 80:1943-84.

- 2004. Risks, Reputations, and Rewards: Contingency Fee Legal Practice in the United States. Stanford, CA: Stanford University Press.

Landsman, Stephan. 2009. "The Growing Challenge of Pro Se Litigation." Lewis and Clark Law Review 13:439-60.

LeRoy, Michael H., and Peter Feuille. 2003. "Judical Enforcement of Predispute Arbitration Agreements: Back to the Future." Ohio State Joumal on Dispute Resolution 18:249-341.

Long, Justin R. 2009. “Against Certification.” George Washington Law Review 78:114-70.

MacCoun, Robert J. 1999. "Epistemological Dilemmas in the Assessment of Legal Decision Making." Law and Human Behavior 23 (6): 723-30.

MacCoun, Robert J., Allan E. Lind, Deborah R. Hensler, David L. Bryant, and Patricia A. Ebener. 1988. Alternative Adjudication: An Evaluation of the New Jersey Automobile Arbitration Program. Santa Monica, CA: RAND.

Martin, Andrew D., and Kevin M. Quinn. 2002. "Dynamic Ideal Point Estimation via Markov Chain Monte Carlo for the U.S. Supreme Court, 1953-1999." Political Analysis 10:134-53.

Mashaw, Jerry L. 1974. "The Management Side of Due Process: Some Theoretical and Litigation Notes on the Assurance of Accuracy, Fairness and Timeliness in the Adjudication of Social Welfare Claims." Comell Law Review 59:772-824.

McDermott, E. Patrick, and Ruth Obar. 2004. "What's Going On' in Mediation: An Empirical Analysis of the Influence of a Mediator's Style of Party Satisfaction and Monetary Benefit." Harvard Negotiation Law Review 9:75-114.

Melnick, R. Shep. 1994. Between the Lines: Interpreting Welfare Rights. Washington, DC: Brookings Institution.

—. 2005. "From Tax-and-Spend to Mandate-and-Sue: Liberalism after the Great Society." In The Great Society and the High Tide of Liberalism, ed. Sidney M. Milkis and Jerome M. Mileur, 387-410. Amherst: University of Massachusetts Press.

Mongoven, Katherine M. 2005. "Impact of Contingency Fee Agreements on 'Reasonable' Attorney Fees Awarded Pursuant to Wisconsin Fee-Shifting Statutes." Marquette Law Review 88:101330.

Moyer, Laura P., and Holley Tankersley. 2012. "Judicial Innovation and Sexual Harassment Doctrine in the U.S. Court of Appeals." Political Research Quarterly 65:784-98.

Murphy, Colleen P. 1995. "Determining Compensation: The Tension between Legislative Power and Jury Authority." Texas Law Review 74:345-410.

Nielsen, Laura Beth, Robert Nelson, and Ryon Lancaster. 2010. "Individual Justice or Collective Legal Mobilization? Employment Discrimination Litigation in the Post Civil Rights United States." Journal of Empirical Legal Studies 7:175-201.

Pardo, Rafael I. 2009. "An Empirical Examination of Access to Chapter 7 Relief by Pro Se Debtors." Emory Bankruptcy Development Journal 26:6-32. 
Pattanayak, Cassandra Wolos, D. James Greiner, and Jonathan Hennessy. 2013. "The Limits of Unbundled Legal Assistance: A Randomized Study in a Massachusetts District Court and Prospects for the Future." Harvard Law Review 126:901-89.

Polinsky, A. Mitchell, and Steven Shavell. 1998. "Punitive Damages: An Economic Analysis." Harvard Law Review 111 (4): 869-962.

Posner, Richard A. 1973. "An Economic Approach to Legal Procedure and Judicial Administration." Journal of Legal Studies 2:399-458.

Priest, George L., and Benjamin Klein. 1984. "The Selection of Disputes for Litigation." Journal of Legal Studies 13 (1): 1-55.

Robbennolt, Jennifer K. 2005. "Evaluating Juries by Comparison to Judges: A Benchmark for Judging?" Florida State University Law Review 32:469-509.

Rosenbloom, Jonathan D. 2002. "Exploring Methods to Improve Management and Fairness in Pro Se Cases: A Study of the Pro Se Docket in the Southern District of New York." Fordham Urban Law Journal 30:305-81.

Schwab, Steward, and Theodore Eisenberg. 1988. "Explaining Constitutional Tort Litigation: The Influence of the Attorney Fees Statute and the Government as Defendant." Comell Law Review 73:719-84.

Segal, Jeffrey A., and Albert Cover. 1989. "Ideological Values and the Votes of U.S. Supreme Court Justices." American Political Science Review 83:557-65.

Segal, Jeffrey A., and Harold J. Spaeth. 2002. The Supreme Court and the Attitudinal Model Revisited. Cambridge: Cambridge University Press.

Seron, Carroll, Martin Frankel, Gregg Van Ryzin, and Jean Kovath. 2001. "The Impact of Legal Counsel on Outcomes for Poor Tenants in New York City's Housing Court: Results of a Randomized Experiment." Law and Society Review 35:419-34.

Shavell, Steven. 1982. "Suit, Settement, and Trial: A Theoretical Analysis under Alternative Methods for the Allocation of Legal Costs." Journal of Legal Studies 11:55-81.

Sunstein, Cass R., Reid Hastie, John W. Payne, David A. Schkade, and W. Vip Viscusi. 2002. Punitive Damages: How Juries Decide. Chicago: University of Chicago Press.

Sunstein, Cass R., David Schkade, and Lisa M. Ellman. 2006. Are Judges Political? An Empirical Analysis of the Federal Judiciary. Washington, DC: Brookings Institution.

Taylor, Christopher. 2009. "Halting the Charge: Overcoming Problems with the Texas Workforce Commission Civil Rights Division and Its Interplay with the Equal Employment Opportunity Commission." Texas Tech Administrative Law Journal 11:139-60.

Taylor, Kelli D. 1994. "The Civil Rights Act of 1991 and Retroactivity: Do Landgraf v. USI Film Products and Rivers v. Roadway Express, Inc. Signify a New Era of Restrictive Employment Discrimination Cases?" American Journal of Trial Advocacy 17:773-95.

Thompson, Timothy D. 2010. "Non-prisoner Pro Se Litigation in the United States District Court for the Eastern District of Kentucky: Analyzing 2004 and 2007 Cases from Filing to Termination." Kentucky Law Journal 99:601-35.

Viscusi, W. Kip. 1991. Reforming Products Liability. Cambridge, MA: Harvard University Press.

Wawro, Gregory J., and Ira Katznelson. 2014. "Designing Historical Social Scientific Inquiry: How Parameter Heterogeneity Can Bridge the Methodological Divide between Quantitative and Qualitative Approaches." American Joumal of Political Science 58:526-46.

Zemans, Frances Kahn. 1984. "Fee Shifting and the Implementation of Public Policy." Law and Contemporary Problems 47 (1): 187-210. 
